Захаренко Людмила Миколаївна кандидат психологічних наук, старший науковий співробітник наукової лабораторії 3 проблем психологічного забезпечення та психофізіологічних досліджень, Національна академія внутрішніх справ, пл. Солом'янська, 1, м. Київ, 03035, тел.: (044) 520-06-74, еmail: zakharenko-luda@ukr.net, https://orcid.org/0000-0002-2121-0862

Юрченко-Шеховцова Тетяна Іванівна кандидат психологічних наук, науковий співробітник наукової лабораторії 3 проблем психологічного забезпечення та психофізіологічних досліджень, Національна академія внутрішніх справ, пл. Солом'янська, 1, м. Київ, 03035, тел.: (044) 520-06-74, еmail: tanusha2307@ukr.net, https://orcid.org/0000-0001-6541-3410

\title{
СУТНІСТЬ ПРОФЕСІЙНОГО ПСИХОЛОГІЧНОГО ВІДБОРУ НА НАВЧАННЯ ЗА ПРОГРАМОЮ ПІДГОТОВКИ ОФІЦЕРІВ ЗАПАСУ
}

Анотація. Інтерес молоді до військової підготовки та захисту своєї країни значно зріс протягом кількох останніх років. Це активізувало потребу комплектування Збройних Сил України кваліфікованими та підготовленими військовими кадрами, зокрема офіцерами запасу. У зв'язку із цим важливим $\epsilon$ здійснення якісного професійного психологічного відбору вступників для проведення військової підготовки за програмою підготовки офіцерів запасу.

Метою дослідження стало емпіричне вивчення морально-ділових якостей вступників на навчання за програмою підготовки офіцерів запасу.

Використані структурно-логічний метод, методи емпіричного психологічного дослідження (тестування), порівняльного аналізу сприяли досягненню мети дослідження. Авторки статті посилаються на нормативні документи, згідно з якими визначено процедуру та особливості проведення професійного психологічного відбору. Емпіричну базу дослідження $(\mathrm{n}=42)$ склали вступники для отримання військової підготовки за програмою підготовки офіцерів запасу на кафедрі військової підготовки Національної академії внутрішніх справ. Наукова новизна. У ході дослідження було виявлено, що вступники на навчання за програмою підготовки офіцерів запасу мотивовані на захист Вітчизни, спрямовані на справу. За результатами проведення професійного психологічного відбору було оцінено професійну придатність вступників до військової служби, успішного навчання і оволодіння обраною військово-обліковою спеціальністю. Висновки. Використаний комплект методик для психодіагностичного вивчення індивідуальних психологічних якостей вступників на навчання за програмою підготовки офіцерів запасу є достатнім для здійснення професійного психологічного відбору та прогнозування успішності їх навчання за обраною військово-обліковою спеціальністю. 
Ключові слова: професійно психологічний відбір, військова підготовка, офіцери запасу.

Zakharenko Liudmyla Mykolaivna Ph. D. in Psychology, senior research fellow, scientific laboratory on psychological support and psychophysiological research of the National Academy of Internal Affairs, Solomyanska Square, 1, Kiev, 03035, tel.: (044) 520-06-74, e-mail: zakharenko-luda@ukr.net, https://orcid.org/0000-0002-21210862 .

Yurchenko-Shekhovtsova Tetiana Ivanivna $\mathrm{Ph}$. D. in Psychology, research fellow, scientific laboratory on psychological support and psychophysiological research of the National Academy of Internal Affairs, Solomyanska Square, 1, Kiev, 03035, tel.: (044) 520-06-74, e-mail: tanusha2307@ukr.net, https://orcid.org/0000-0001-65413410 .

\section{THE ESSENCE OF PROFESSIONAL PSYCHOLOGICAL SELECTION FOR TRAINING IN THE STOCK TRAINING PROGRAM}

Abstract. the interest of young people to military training and protect its country has increased significantly over the past few years. This intensified the need to complete the armed forces of Ukraine with qualified and prepared military personnel, including stock officers. In this regard, it is important to carry out a qualitative professional psychological selection of entrants for military training under the program for the preparation of stock officers.

The purpose of the study was the empirical study of the moral and business qualities of entrants to study programs for the preparation of stock officers.

Used structural-logical method, methods of empirical psychological research (testing), comparative analysis contributed to the achievement of the purpose of the study. The author of the article references to the normative documents, according to which the procedure and features of professional psychological selection are determined. The empirical base of the study $(n=42)$ amounted to entrants for obtaining military training under the Program for the preparation of stock officers at the Department of Military Training of the National Academy of Internal Affairs. Scientific novelty. During the study, it was discovered that entrants for training programs for the preparation of stock officers are motivated to protect the Fatherland aimed at the case. According to the results of professional psychological selection, the professional suitability of entrants to military service, successful training and mastery was evaluated by the chosen military-accounting specialty. Conclusions. The set of techniques for the psychodiagnostic study of individual psychological qualities of entrants to study programs for the training of stock officers is sufficient to carry out professional psychological selection and forecasting the success of their training for the chosen military-accounting specialty. officers.

Keywords: professionally psychological selection, military training, stock 
Постановка проблеми. Протягом кількох останніх років значно зріс інтерес молоді до військової підготовки та захисту своєї країни [6; 8; 10]. Проведення Операції Об'єднаних сил на сході нашої держави поставили перед суспільством потребу у комплектуванні Збройних Сил України кваліфікованими та підготовленими військовими кадрами. Зважаючи на це важливим стало відкриття військових підрозділів на базі закладів вищої освіти, які здійснюють підготовку офіцерів запасу. Це надало можливість патріотично налаштованій молоді вступити на навчання за програмою підготовки офіцерів запасу, пройти повний курс військової підготовки, опанувати військово-облікову спеціальність та отримати первинне військове звання «молодший лейтенант запасу».

Однак обов'язковим $є$ проходження вступниками професійного психологічного відбору 3 метою визначення їх придатності до успішного навчання і оволодіння військовою спеціальністю.

Аналіз останніх досліджень і публікацій. Важливі аспекти професійного психологічного відбору військовозобов'язаних розглянуті у працях Василенка С., Гришина С., Кузьменка М., Малюги В., Приходька I., Стасюка В. тощо. Однак професійний психологічний відбір вступників на навчання за програмою підготовки офіцерів запасу недостатньо висвітлений у наукових публікаціях.

Чинною нормативно-правовою базою передбачено, що комплект методик професійного психологічного відбору для навчання за програмою підготовки офіцерів запасу включає методики 3 оцінки військово-мотиваційної спрямованості особистості; рівня нервово-психічної стійкості; оцінки професійної придатності до успішного навчання i оволодіння відповідною військовою спеціальністю [2; 3; 4]. Науковці зазначають, що фаховій підготовці офіцерів повинні передувати якісний професійний психологічний відбір, практичне навчання у військових підрозділах закладів вищої освіти за військовообліковими спеціальностями та морально-патріотичне виховання [5; 6; 9]. Саме тому метою статті є вивчення морально-ділових якостей вступників на навчання за програмою підготовки офіцерів запасу.

Виклад основного матеріалу. У дослідженні використані:

1) анкета «Картка вивчення кандидата на навчання» для оцінки військовомотиваційної спрямованості особистості;

2) психогеометричний тест «Шкала прогресивних матриць Равена» (автори Джон Рейвен і Л. Пенроуз) для оцінки рівня розвитку інтелекту респондентів;

3) опитник Ч. Д. Спілберга (шкала особистісної тривожності) для оцінки рівня особистісної тривожності;

4) опитник MPI (методика Г. Айзенка) для діагностики індивідуальнопсихологічних властивостей особистості (екстраверсія та нейротизм);

5) багатофакторний особистісний опитник «Адаптивність» (МЛО-АМ) А. Г. Маклакова, С. В. Чермяніна для оцінки особистісних адаптивних 
здібностей, нервово-психічної стійкості, комунікативних здібностей, моральної нормативності.

У дослідженні використовувались структурно-логічний метод, методи емпіричного психологічного дослідження (тестування), порівняльного аналізу. Статистична обробка даних проводилася за допомогою функцій та формул версії Excel, яка входить у програмний пакет Microsoft Office 2007.

Емпірична база дослідження (вибірка): 42 вступники (28 осіб чоловічої статі, 14 - жіночої статі), які мають або здобувають ступінь вищої освіти не нижче бакалавра, придатні до військової служби за станом здоров'я для отримання військової підготовки за програмою підготовки офіцерів запасу на кафедрі військової підготовки Національної академії внутрішніх справ.

\section{Завдання дослідження:}

1) оцінити військово-мотиваційну спрямованість вступників на навчання за програмою підготовки офіцерів запасу;

2) дослідити рівень їх особистісних адаптивних здібностей, зокрема рівень нервово-психічної стійкості, та індивідуальні психологічні якості;

3) оцінити професійну придатність вступників до успішного навчання i оволодіння обраною військовою спеціальністю;

4) за результатами оцінки індивідуальних психологічних якостей вступників на навчання за програмою підготовки офіцерів запасу визнати тих, хто пройшов професійний психологічний відбір, i тих, хто не пройшов професійний психологічний відбір;

5) визначити ефективність підібраного комплекту методик 3 метою психодіагностичного вивчення індивідуальних психологічних якостей кандидатів на навчання за програмою підготовки офіцерів запасу та прогнозування успішності їх навчання за обраною військово-обліковою спеціальністю.

Гіпотеза дослідження: індивідуальні психологічні якості вступників визначають їх придатність до успішного навчання i оволодіння військовою спеціальністю.

За результатами проведення анкети «Картка вивчення кандидата на навчання» було визначено, що особистісна військово-мотиваційна спрямованість кандидатів на навчання за програмою підготовки офіцерів запасу характеризується, насамперед, спрямованістю на задачу («захищати свою країну»), на взаємодію («працювати в силових відомствах»), на себе («отримати офіцерське звання»).

За допомогою шкали прогресивних матриць Равена (тест Равена) було оцінено рівень розвитку інтелекту респондентів. Після проходження всіх серій тесту Равена респондентами було отримано такі показники (табл. 1). 
Кількісні показники інтелекту респондентів (в балах)

\begin{tabular}{|c|c|c|c|c|c|c|}
\hline & Серія А & Серія В & Серія С & Серія D & Серія E & Заг. кіл-сть \\
\hline Min & 9 & 4 & 4 & 2 & 0 & 33 \\
\hline Max & 12 & 12 & 12 & 11 & 11 & 57 \\
\hline M & 11,67 & 10,9 & 9,19 & 9 & 5,7 & 46 \\
\hline
\end{tabular}

На основі відсоткової шкали було визначено кількісний показник інтелекту (IQ) респондентів. Загальна кількість балів (мінімальна та максимальна), отриманих за результатами діагностики, дорівнює 33 і 57 балів, що відповідає кількісним значенням показника коефіцієнту інтелекту (IQ) опитаних від 86 до 126 (з поправкою на вік).

Оцінка рівня розвитку інтелекту респондентів проводилась на основі шкали розумових здібностей. Орінтуючись на виявлений IQ респондентів було визначено рівень їх розумових здібностей (табл. 2).

Таблиия 2

Розподіл респондентів у групи відповідно до рівня розумових здібностей (кількість осіб)

\begin{tabular}{|c|c|c|c|c|}
\hline Високий & Вище середнього & Середній & Нижче середнього & Низький \\
\hline 3 & 10 & 28 & 1 & - \\
\hline
\end{tabular}

Відповідно до виявленого показника IQ було визначено, що рівень розвитку інтелекту абітурієнтів - від нижче середнього до високого.

Більшості респондентів (67\%) характерний середній рівень розумових здібностей, майже у кожного четвертого (24\%) респондента рівень розумових здібностей вище середнього рівня розвитку. Лише незначна кількість респондентів мають високий (7\%) і нижче середнього (2\%) рівень розвитку розумових здібностей. Осіб із низьким рівнем розумових здібностей немає.

Отже, проведена оцінка розумових здібностей респондентів дозволяє прогнозувати труднощі в навчанні та оволодінні військовою спеціальністю особи 3 інтелектом нижче середнього рівня.

Використання опитника Ч. Д. Спілберга (шкала особистісної тривожності) дозволило визначити кількісні показники та рівень особистісної тривожності респондентів. Особистісна тривожність $\epsilon$ стійкою індивідуальною характеристикою, що відображає здатність суб'єкта до тривоги та активізується при сприйнятті певних стимулів, які розцінюються як загрозливі [7; 9].

3'ясовано, що особистісна тривожність набуває значень від 22 до 45 балів (середньогрупове значення 31,6 бали). При інтерпретації показників використовувались наступні орієнтовні оцінки тривожності: до 30 балів - низька, 31-44 - помірна, 45 і більше - висока. Встановлено, що майже половина респондентів характеризується помірним рівнем особистої тривожності, лише одна особа - високим рівнем, і майже половина решта - низьким (табл. 3). 


\section{Розподіл респондентів у групи відповідно до рівня особистісної} тривожності (кількість осіб)

\begin{tabular}{|c|c|c|}
\hline Висока тривожність & Помірна тривожність & Низька тривожність \\
\hline 1 & 21 & 20 \\
\hline
\end{tabular}

Відповідно до табличних даних у вибірці майже однакова кількість осіб із помірною та низькою тривожністю. Виявлена одна високо тривожна особа, якій притаманні підвищена схильність до переживань тривоги і занепокоєння без достатніх підстав.

За допомогою опитника MPI (методика Г. Айзенка) було визначено показники таких індивідуально-психологічних властивостей респондентів як екстраверсія та нейротизм (табл. 4).

Таблиия 4

Середньогрупові показники за шкалами опитника Г. Айзенка (в балах)

\begin{tabular}{|l|c|c|c|}
\hline & $\begin{array}{c}\text { Шкала } \\
\text { «iнтроверсія - } \\
\text { екстраверсія» }\end{array}$ & $\begin{array}{c}\text { Шкала } \\
\text { «нейротизм - } \\
\text { стабільність» }\end{array}$ & $\begin{array}{c}\text { Шкала } \\
\text { брехні }\end{array}$ \\
\hline Min & 8 & 3 & 4 \\
\hline Max & 20 & 22 & 17 \\
\hline M & 16 & 9,02 & 10,2 \\
\hline
\end{tabular}

Відповідно до даних таблиці показники за шкалою інтроверсії екстраверсії у межах 8-20 балів вказують на наявність серед опитуваних інтровертів, екстравертів та яскравих екстравертів. 3 числа опитаних 35 осіб екстраверти, 5 осіб - яскраві екстраверти, 2 особи - інтроверти.

Показники за шкалою нейротизму - стабільності сягають від низьких (3 бали) до дуже високих (22) значень. Більшості респондентів (38 осіб) характерні низькі та середні показники нейротизму, а 2 особам - високий рівень нейротизму, 2 особам - дуже високий рівень нейротизму.

Відповідно респондентам характерні такі типи темпераменту: сангвінік (стабільний, екстравертований) - 29 осіб; холерик (нестабільний, екстравертований) - 8 осіб; меланхолік (нестабільний, інтровертований) - 4 особи; флегматик (стабільний, інтровертований) - 1 особа.

Отже, виділено респондентів 3 дуже високим рівнем нейротизму (по одній особі з холеричним та меланхолічним типами темпераменту), з високим рівнем нейротизму (одна особа холеричного типу темпераменту).

За допомогою опитника МЛО було оцінено особистісний адаптивний потенціал респондентів. Відповідно до рівня розвитку адаптаційних здібностей респонденти були розподілені у групи (табл. 5). 
Показники адаптаційних здібностей респондентів (кількість осіб)

\begin{tabular}{|c|c|c|c|c|}
\hline & $\begin{array}{c}\text { Нервово- } \\
\text { психічна } \\
\text { стійкість }\end{array}$ & $\begin{array}{c}\text { Комунікативн } \\
\text { і особливості }\end{array}$ & $\begin{array}{c}\text { Моральна } \\
\text { нормативніс } \\
\text { ть }\end{array}$ & $\begin{array}{c}\text { Особистісни } \\
\text { й потенціал }\end{array}$ \\
\hline $\begin{array}{c}\text { Високий } \\
\text { рівень }\end{array}$ & 20 & 7 & 3 & 6 \\
\hline $\begin{array}{c}\text { Середній } \\
\text { рівень }\end{array}$ & 17 & 30 & 32 & 23 \\
\hline $\begin{array}{c}\text { Низький } \\
\text { рівень }\end{array}$ & $\mathbf{5}$ & $\mathbf{5}$ & $\mathbf{7}$ & $\mathbf{4}$ \\
\hline
\end{tabular}

Згідно 3 отриманими даними особистісний потенціал респондентів на високому і середньому (29 осіб), низькому (4 особи) рівнях розвитку.

Більшість респондентів мають високий чи середній рівень нервово-психічної стійкості (88\%, 37 осіб), середні рівні розвитку комунікативних здібностей $(71 \%$, 30 осіб) та моральної нормативності (76\%, 32 особи).

Визначено респондентів, які мають високий рівень комунікативних здібностей $(17 \%, 7$ осіб), моральної нормативності (7\%, 3 особи) та низький рівень моральної нормативності 17\% (7 осіб). Незадовільна нервово-психічна стійкість і низький рівень поведінкової регуляції (12\%, 5 осіб) або труднощі у встановленні нових контактів 3 оточуючими $(12 \%, 5$ осіб) характерні для кожного дев'ятого респондента.

Відповідно до визначеного рівня розвитку особистісного адаптаційного потенціалу респонденти були розподілені у групи адаптації (табл. 6).

Таблиия 6

Розподіл респондентів у групи адаптації відповідно до рівня розвитку адаптаційних здібностей (кількість осіб)

\begin{tabular}{|c|c|c|}
\hline $\begin{array}{c}\text { Група високої і нормальної } \\
\text { адаптації }\end{array}$ & $\begin{array}{c}\text { Група задовільної } \\
\text { адаптації }\end{array}$ & $\begin{array}{c}\text { Група низької } \\
\text { адаптації }\end{array}$ \\
\hline 30 & 7 & 5 \\
\hline
\end{tabular}

Згідно $з$ даними таблиці більшість опитаних (71\%, 30 осіб) емоційно стійкі, можуть легко адаптуватися до нових умов діяльності, здатні адекватно зорієнтуватися у ситуації, швидко виробити стратегію своєї поведінки.

Майже у кожного п’ятого з числа опитаних $(17 \%, 7$ осіб) успішність адаптації залежить від зовнішніх умов середовища, що у звичних умовах компенсується, але може проявлятися при зміні діяльності. Їхня емоційна стійкість задовільна, хоча можливі прояви конфліктності.

До групи низької адаптації віднесено опитаних (12\%, 5 осіб), яким характерні емоційна нестійкість, акцентуйовані риси характеру, конфліктність, межовий психічний стан через що успішність їх адаптації буде низькою. 


\section{Висновки:}

1. Вступники на навчання за програмою підготовки офіцерів запасу здебільшого мають ділову спрямованість та мотивовані на захист Вітчизни.

2. Їхні особистісні адаптивні здібності достатні для військової служби у звичайних та екстремальних умовах, успішного виконання завдань згідно 3 військово-обліковою спеціальністю. Вступники з нервово-психічною нестійкістю визнані такими, що не пройшли професійний психологічний відбір.

3. Проведене психодіагностичне вивчення індивідуальних психологічних якостей вступників на навчання за програмою підготовки офіцерів запасу дозволило визначити тих з них, хто пройшов професійний психологічний відбір, $\mathrm{i}$ тих, хто не пройшов професійний психологічний відбір.

4. За результатами оцінки професійної придатності вступників до успішного навчання було рекомендовано обрати іншу військово-облікову спеціальність окремим з них.

5. Використаний комплект методик для психодіагностичного вивчення індивідуальних психологічних якостей вступників на навчання за програмою підготовки офіцерів запасу є достатнім для професійного психологічного відбору та прогнозування успішності навчання за військово-обліковою спеціальністю.

\section{Jimepamypa:}

1. Про військовий обов’язок та військову службу : Закон України від 25.03 .1992 р. № 2232 - XII (зі змінами від 23.05.2021 p.) URL: https://zakon.rada.gov.ua/laws/show/2232-12\#Text.

2. І Інструкція про організацію військової підготовки громадян України за програмою підготовки офіцерів запасу на кафедрі військової підготовки Національної академії внутрішніх справ. URL: https://www.naiau.kiev.ua/zagalnoakademichni-kafedri/kafedra-vijskovoyi-pidgotovkinavs/diyalnist-kafedri-vijskovoyi-pidgotovki/instrukciya-pro-organizaciyu-vijskovoyi-pidgotovkigromadyan-ukrayini-pidgotovki-oficeriv-zapasu.pdf

3. Про затвердження Інструкції 3 організації та проведення професійного психологічного відбору кандидатів на навчання у вищих військових навчальних закладах та військових навчальних підрозділах вищих навчальних закладів : наказ Міністра оборони України від 09.07.2009 № 355. URL: https://zakon.rada.gov.ua/laws/show/z0893-09\#Text.

4. Про затвердження Інструкції про організацію військової підготовки громадян України за програмою підготовки офіцерів запасу : наказ Міністерства оборони України, Міністерства освіти і науки України від 14.12.2015 № 719/1289. URL: https://zakon.rada.gov.ua/laws/show/z1678-15\#Text.

5. Баришніков В. В., Неймирок О. К. Шляхи вдосконалення підготовки офіцерів запасу в Україні. Системи обробки інформації. 2015. Вип. 8 (133). С. 158-161.

6. Зорій Я. Б., Хомчак Р. Б. Особливості військово-професійної підготовки майбутніх офіцерів запасу у вищих навчальних закладах України. 3б-к наукових пращь Херсонського державного університету. Педагогічні науки. 2018. Вип. 81(1). С. 143-150. URL: http://nbuv.gov.ua/UJRN/znppn_2018_81\%281\%29_29.

7. Корольчук М. С. Соціально-психологічне забезпечення діяльності в звичайних та екстремальних умовах: навч. посіб. для студентів вищ. навч. закладів. Київ: Ніка-Центр, 2006. $580 \mathrm{c}$.

8. Кузьменко М., Гришин С., Малюга В. Актуальні проблеми психологічного вивчення військовозобов'язаних для проходження військової служби за призовом на посадах осіб офіцерського складу. Вісник Київського національного університету імені Тараса Шевченка. Військово-спещіальні науки. 2015. 1(32). С. 17-21. 
9. Стасюк В. В., Василенко С. В. Сутність професійно-психологічного відбору військовослужбовців до діяльності в екстремальних умовах. Проблеми екстремальної та кризової психології. 2010. Вип. 8.2 С. 137-145. URL: https://nuczu.edu.ua/sciencearchive/ProblemsOfExtremeAndCrisisPsychology/vol8/018.pdf

10. Черних Ю., Черних О. Аналіз деяких проблем підготовки офіцерів запасу у Військовому інституті: підсумки соціологічного опитування. Вісник Київського Наџіонального університету імені Тараса Шевченка. Військово-спеціальні науки. 2019. 2(42). С. 64-70.

\section{References:}

1. Pro viiskovyi oboviazok ta viiskovu sluzhbu : Zakon Ukrainy vid 25.03.1992 r. № 2232 - XII (zi zminamy vid 23.05.2021 r.). [About Military Duty and Military Service: Law of Ukraine dated March 25, 1992 No. 2232 - XII (with changes from 23.05.2021]. URL: https://zakon.rada.gov.ua/laws/show/2232-12\#Text. [in Ukrainian].

2. Instruktsiia pro orhanizatsiiu viiskovoi pidhotovky hromadian Ukrainy za prohramoiu pidhotovky ofitseriv zapasu na kafedri viiskovoi pidhotovky Natsionalnoi akademii vnutrishnikh sprav. [Instruction on the organization of military training of Ukrainian citizens under the Program for the preparation of stock officers at the Department of Military Training of the National Academy of Internal Affairs]. URL: https://www.naiau.kiev.ua/zagalnoakademichni-kafedri/kafedra-vijskovoyipidgotovki-navs/diyalnist-kafedri-vijskovoyi-pidgotovki/instrukciya-pro-organizaciyu-vijskovoyipidgotovki-gromadyan-ukrayini-pidgotovki-oficeriv-zapasu.pdf [in Ukrainian].

3. Pro zatverdzhennia Instruktsii $\mathrm{z}$ orhanizatsii ta provedennia profesiinoho psykholohichnoho vidboru kandydativ na navchannia u vyshchykh viiskovykh navchalnykh zakladakh ta viiskovykh navchalnykh pidrozdilakh vyshchykh navchalnykh zakladiv : nakaz Ministra oborony Ukrainy vid 09.07.2009 № 355. [On Approval of Instructions for Organization and Professional Psychological Selection of candidates for studying in higher military educational institutions and military educational units of higher educational institutions: Order of the Minister of Defense of Ukraine dated 09.07.2009 No. 355]. URL: https://zakon.rada.gov.ua/laws/show/z089309\#Text. [in Ukrainian].

4. Pro zatverdzhennia Instruktsii pro orhanizatsiiu viiskovoi pidhotovky hromadian Ukrainy za prohramoiu pidhotovky ofitseriv zapasu : nakaz Ministerstva oborony Ukrainy, Ministerstva osvity i nauky Ukrainy vid 14.12.2015 № 719/1289. [Approval of the Instructions on the organization of military training of Ukrainian citizens under the Program for the preparation of stock officers: Order of the Ministry of Defense of Ukraine, Ministry of Education and Science of Ukraine dated 14.12.2015 No. 719/1289]. URL: https://zakon.rada.gov.ua/laws/show/z1678-15\#Text. [in Ukrainian].

5. Baryshnikov V. V. \& Neimyrok O. K. (2015). Shliakhy vdoskonalennia pidhotovky ofitseriv zapasu v Ukraini. [Ways to improve the preparation of stock officers in Ukraine]. Systemy obrobky informatsii. Vyp. 8 (133). S. 158-161. [in Ukrainian].

6. Zorii Ya. B. \& Khomchak R. B. (2018). Osoblyvosti viiskovo-profesiinoi pidhotovky maibutnikh ofitseriv zapasu u vyshchykh navchalnykh zakladakh Ukrainy. [Features of militaryprofessional training of future stock officers in higher educational institutions of Ukraine]. $Z b-k$ naukovykh prats Khersonskoho derzhavnoho universytetu. Pedahohichni nauky. Vyp. 81(1). S. 143150. URL: http://nbuv.gov.ua/UJRN/znppn_2018_81\%281\%29_29. [in Ukrainian].

7. Korolchuk M. S. (2006). Sotsialno-psykholohichne zabezpechennia diialnosti v zvychainykh ta ekstremalnykh umovakh [Socio-psychological support of activities in normal and extreme conditions]: navch. posib. dlia studentiv vyshch. navch. zakladiv. Kyiv: Nika-Tsentr [in Ukrainian].

8. Kuzmenko M. \& Hryshyn S. \& Maliuha V. (2015). Aktualni problemy psykholohichnoho vyvchennia viiskovozoboviazanykh dlia prokhodzhennia viiskovoi sluzhby za pryzovom na posadakh osib ofitserskoho skladu. [Actual problems of psychological study of conscripts for military service on conscription as officers]. Visnyk Kyivskoho natsionalnoho universytetu imeni Tarasa Shevchenka. Viiskovo-spetsialni nauky. 1(32). S. 17-21. [in Ukrainian]. 
9. Stasiuk V. V. \& Vasylenko S. V. (2010). Sutnist profesiino-psykholohichnoho vidboru viiskovosluzhbovtsiv do diialnosti $\mathrm{v}$ ekstremalnykh umovakh. [The essence of professional and psychological selection of servicemen to work in extreme conditions]. Problemy ekstremalnoi ta kryzovoi psykholohii. Vyp. 8. S. 137-145. URL: https://nuczu.edu.ua/sciencearchive/ ProblemsOfExtremeAndCrisisPsychology/vol8/018.pdf [in Ukrainian].

10. Chernykh Yu. \& Chernykh O. (2019). Analiz deiakykh problem pidhotovky ofitseriv zapasu u Viiskovomu instytuti: pidsumky sotsiolohichnoho opytuvannia. [Analysis of some problems in the training of reserve officers at the Military Institute: the results of a poll]. Visnyk Kyivskoho Natsionalnoho universytetu imeni Tarasa Shevchenka. Viiskovo-spetsialni nauky. 2(42) S. 64-70. [in Ukrainian]. 